\title{
MALAYSIAN HOSPITALITY INDUSTRY: GRADUATES' JUSTIFICATIONS FOR LEAVING THE INDUSTRY
}

\author{
ROZILA AHMAD \\ BASRI RASHID \\ NURHAZANI MOHD SHARIFF \\ School of Tourism, Hospitality and Environmental Management \\ Universiti Utara Malaysia
}

\begin{abstract}
Continuous skilled-employee shortage has been reported in the hospitality industry despite the mushrooming growth of higher learning institutions offering the Bachelor of Hospitality Management (BHM) programme. The purpose of this study is to assess the BHM graduates' areas of employment and their justification for not seeking employment or leaving the hospitality industry. To meet the purpose, a quantitative research paradigm supported by open-ended questions was used. This study focused on Universiti Utara Malaysia (UUM) BHM graduates. The findings revealed that the UUM BHM graduates' Islamic faith plays a significant role in the religious Muslim graduates' career paths. However, as widely documented in the literature, unattractive compensation in the hospitality industry appears to be the most important reason for graduates to seek employment in other industries. This is followed by poor career development opportunities and working conditions. Information from this study may help remedy the continuous shortage of skilled employees in the industry. It may also ensure the graduates' ability to secure suitable jobs. In addition, it indirectly helps in the initiative to improve the BHM curriculum.
\end{abstract}

Keywords: Hospitality, workforce, graduate, employment, hospitality industry, career, Malaysia.

\section{Introduction}

A shortage of skilled employees in the Malaysian hospitality industry is continuously reported despite the increasing number of colleges and universities offering the Bachelor in Hospitality Management (BHM) Programme (Ahmad \& Zainol, 2011; Zahari, Hanafiah, Othman, 
Jamaluddin \& Zulkifly, 2010). While many argue that the industry failed to provide appealing working conditions, hotel managers claim that fresh graduates do not have sufficient knowledge, skills and capabilities to hold supervisory or management positions (Ahmad \& Zainol, 2011; Patah, Zain, Abdullah \& Radzi, 2009).

Very few fresh graduates enter the hospitality industry and many of them decide not to pursue a full- time or long-term career in the industry (Zahari et al., 2010). This is caused by a number of industryspecific characteristics, such as low pay and formal qualifications, high proportion of low-skilled jobs, working a lot outside normal business hours, a negative industry image, poor utilization of student labour and a high level of employee turnover (Richardson \& Butler, 2011).

Researchers have sought hotel managers' and students' points of view on the issue of skilled-employee shortage in the hospitality industry in Malaysia (Ahmad \& Zainol, 2011; Patah et al., 2010; Richardson \& Butler, 2011; Zahari et al., 2010). However, the effort to look at the issue from the graduates' perspective has been very limited despite the fact that graduates are an important subject of the issue. In Malaysia, little research has been published investigating tourism and hospitality graduates' justification for not joining or leaving the industry especially those focusing on BHM graduates.

The Malaysian Ministry of Higher Education continuously conducts surveys to track Malaysian universities graduates' employability (Tracer Study). However, the main purpose of the surveys is to assess graduates' views of the facilities and services provided by their higher learning institutions, and their experience in seeking employment upon the completion of their studies (MOHE, 2013). The surveys mainly assess the graduates' employability within six months of their graduation. It neither provides information on graduates' specific areas of employment nor their explanation for not working in the hospitality industry. Furthermore, although the cause of continuous skilled-employee shortage in the hospitality industry has been widely studied among hospitality graduates in other countries, investigating the issue from the Malaysian graduates' perspective remains crucial because of the socio-cultural differences that exist between local and overseas graduates.

Due to time and budget limitations, this study focused on Universiti Utara Malaysia (UUM) graduates. UUM is one of the few public universities in Malaysia offering the BHM programme, following 
the lead of University Institute of Technology Mara which started offering the programme since 1967 (Shariff, 2011). BHM with Honours has been offered in UUM since 2004. It is a four-year programme which includes six months of industrial training (internship). UUM is selected because the authors are the university's academicians and the research is funded by the university.

According to Shariff (2011) the UUM BHM programme curriculum structure-which comprises of business functional skills, hospitality functional skills, personal skills and analytical skills-complies with the industry's expectations. However, when compared to other universities especially at the international level, it would be a challenge for the programme to survive in the long-term. Foreign hospitality-industry experts suggest that Islamic and Civilization courses should be included in the analytical skill component due to its role in determining the future challenges in the hospitality industry (Shariff, 2011).

To fill the gap in the literature, this study aims to assess the Malaysian BHM graduates' employment areas and explore why BHM graduates pursue their career in other industries. The research questions of this study are:

1. What are the areas of BHM graduates' employment?

2. Why do BHM graduates seek employment in other industries?

\section{Literature Review}

\section{Career in the Hospitality Industry}

Career refers to a personal direction in working life and the future (Ladkin, 2002). While the traditional career model conceived career as a full-time and long-term employment within a limited number of organizations, advocates of the new career-thinking argue that careers are becoming boundless and are influenced by the sociocultural and economic factors of the current business context (Enache, Sallan, Simo, \& Fernandez, 2011). According to Enache et al. (2011), companies are susceptible to economic changes and there are times when they are not able to offer job security and progressive careers. Thus, individuals who take active responsibility in managing their career paths move within and across organizational boundaries for the development of their own careers. 
Worldwide, almost half of all hospitality and tourism graduates either have never entered the industry or left the industry within a few years (Kang \& Gould, 2002; King, McKercher \& Waryszak, 2003). In Taiwan, only thirty-nine per cent of BHM graduates entered the hospitality workforce and this is low compared to employment in other industries (Teng, 2008). The percentage is lower in Australia and Hong Kong where only twenty-four per cent of Australian graduates and thirty- two per cent of Hong Kong graduates are working in the hospitality industry (King et al., 2003). While the Australian graduates were employed for middle to senior management positions, the Hong Kong graduates were employed in lower positions such as administrations, executives, officers, research assistants and sales persons (King et al., 2003). For those who entered the industry it was normal for them to move among hospitality companies to develop their careers (Walsh \& Taylor, 2007). In their first two years, many graduates changed jobs at least twice (McKercher, Williams \& Coghlan, 1995). In Taiwan, BHM graduates generally left their jobs in the hospitality industry due to poor job satisfaction (Teng, 2008). Graduates who left the industry were either seeking for more challenging opportunities in other industries or furthering their education (Raybould \& Wilkins, 2005). When the graduates find work in other industries, the loss of potential talented managers is damaging to the hospitality industry (King et al., 2003; Walsh \& Taylor, 2007). However, the graduates should not be blamed because in comparison to other industries, hospitality jobs are perceived as mundane and poorly compensated, in addition to the long and inflexible working hours (Walsh \& Taylor, 2007).

\section{Issues in the Malaysian Hospitality Industry}

Like in other countries, the Malaysian hospitality industry is confronting problems such as a shortage of skilled personnel and high employee turnover (Kang \& Gould, 2002; Patah et al., 2010). One of the main reasons for the low employment rate is graduating students holding unfavourable attitudes towards getting hospitality jobs upon graduation (Patah et al., 2010; Teng, 2008). Bad experiences during practical training have made some of the hospitality students decided not to join the industry after graduation (Patah et al., 2010). Prior to graduation, hospitality students are required to go through practical training in the industry. However, practical training does not always represent the quality of learning desired by the students and the academics because some students are treated as cheap sources of labour whose development needs are set aside (Lashley, 2011). 
Richardson and Butler (2011) explored the Malaysian Tourism and Hospitality students' views on a career in the hospitality industry and concluded that students do not believe that a career in the industry will offer them the factors that they find important. Among the important factors are higher wages, work-life balance and improved relationship between managers and employees. Personality traits and attitudes also affect a student's uptake and employment in the hospitality industry. According to Teng (2008), extroverted individuals are more service-oriented and they fit well with hospitality jobs. They are sociable, outgoing and gregarious, and are likely to develop positive interpersonal relationships with others.

In Malaysia, hospitality graduates' employment or promotion to the management level is not guaranteed (Ahmad \& Zainol, 2011). Managers in the hospitality industry perceived that hospitality graduates are over-qualified academically but lack working experience (Ahmad \& Zainol, 2011; Raybould \& Wilkins, 2005). Raybould and Wilkins (2005) argued that the skills gained from the management activities of the higher level supervisory staff, namely problem-solving, and conceptual and analytical skills, are the skills that qualify them for the lower management position in the industry. Hospitality graduates lack these skills because operational experience through internships rarely provides them the opportunity to practice management skills. The lack of development opportunity is obvious when the industry continues to assign them operational activities during their first few years of employment (Ahmad \& Zainol, 2011; Raybould \& Wilkins, 2005). Hotel managers are more convinced of promoting their long-serving, well-known and experienced supervisors to management positions instead of filling the management positions with hospitality degree holders who have just graduated (Ahmad \& Zainol, 2011). Concerned about the excessive supply of hospitality graduates that might lead to unemployment, Raybould and Wilkins (2005) suggest that hospitality schools encourage the establishment of more traineeships and increase curriculum emphasis on business entrepreneurship.

\section{Graduates are Taking Charge of Their Careers}

Factors such as poor working conditions, poor compensation, high pressure, physically exhausting repetitive jobs, long working hours, lack of motivation, training programs and development opportunities reduce hospitality graduates' inspiration to seek employment in the industry (Kang \& Gould, 2002; Teng, 2008; Walsh \& Taylor, 2007). The 
routine nature of the jobs in the hospitality industry, and the fact that many posts in the industry do not possess intrinsically high levels of satisfaction for many workers make employment in the industry appear less appealing when compared to other industries (Ryan, Ghazali \& Mohsin, 2011). Hospitality employees earn the lowest pay compared to other industries and service sectors (Teng, 2008). Graduates' lack of interest to remain in the industry is also caused by unfulfilled expectations (Raybould \& Wilkins, 2005) and better opportunities in other industries (Walsh \& Taylor, 2007).

A study by Walsh and Taylor (2007), using a sample of Cornell University School of Administration graduates, discovered that graduates who had become hospitality managers took charge of their careers by looking for challenging jobs that offered growth opportunities, competent leadership and fair compensation. Their statistical tests revealed that jobs that include work challenges lessen the graduates' intention to leave the organization and the hospitality industry. According to them, compensation has some influence on the turnover intention-although not the chief factor, it is important for the graduates to obtain good compensation together with balanced-work-and-personal lives. The importance of challenging jobs with growth opportunities, competent leadership and fair compensation is consistent with the talent development system which includes recruitment and selection, career management, training and development, succession planning, performance management, compensation and benefits and strategic HR planning (Scott \& Revis, 2008).

\section{Methodology}

The purpose of this study is to assess the Malaysian BHM graduates' employment areas and to explore why the graduates pursue their career in other industries. Thus, this study used the quantitative research paradigm supported by open-ended questions. Selfadministered questionnaires were used to collect data. Qualitative data was analysed using content analysis. A population study was conducted to maximize the number of respondents. The population was the total number of UUM BHM students who graduated in the years 2008 to 2012. The graduates were identified from the UUM Alumni office and were contacted through Facebook, e-mails and phone calls. Based on the list of graduates identified, 342 graduates were contacted. Out of the 342 graduates from the list, 237 were 
unreachable and were eliminated from the population. The graduates were unreachable for several reasons: no response via e-mails and phone calls, had changed phone numbers or were working abroad.

The questionnaire consisted of close-ended questions on demographic factors and employment profile. Open-ended questions were included in the questionnaire to acquire more information regarding the cause of graduates' career choice. The questionnaire was in English because all the graduates were expected to comprehend and utilize English for three reasons. Firstly, English language is widely used in the hospitality industry. Secondly, the English requirement for BHM enrolment is at least a Band 3 in the Malaysian University English Test result. Thirdly, English language is the official language used in the teaching and learning of BHM.

Data collection commenced in June 2012, and was carried out for almost 10 months. The graduates were informed that their involvement was voluntary and the information given would be kept confidential. Initially, the questionnaires were circulated through the graduates' e-mails and Facebook but the response rate was very low. Only 28 graduates responded. To increase the response rate, the graduates who did not respond were contacted using the telephone. To work within the budget, international graduates and graduates working abroad were taken out from the list. A phone survey interview was conducted using the same questionnaire and this method tremendously increased the response rate to 105 respondents. All graduates who were reachable through the phone responded to the survey interview. A research assistant was hired to conduct the time-consuming phone survey interview. The research assistant had neither met nor taught the graduates. It was important to ensure that such a relationship did not exist between the research assistant and the graduates to avoid response bias. Thematic content analysis was used to analyse the answers to the open-ended questions where the respondents' answers were grouped into themes.

\section{Results}

Overall, 89 questionnaires were usable to answer research question 1 . The majority 41 of the respondents $(46.1 \%)$ graduated in 2012 . This was followed by 19 respondents (21.3\%) who graduated in 2011, 14 respondents (15.7\%) in 2010, 12 respondents (13.5\%) in 2009 and three respondents (3.4\%) in 2008. Most 64 of the respondents were female 
$(71.9 \%)$ and only 25 respondents $(28.1 \%)$ were male. The majority 53 of the respondents were Muslims (59.6\%), and this was followed by 27 Buddhists (30.3\%), 5 Christians (5.6\%), 3 Hindus (3.4\%), and 1 from other religion (1.1\%). Most 76 of the respondents were single $(85.4 \%)$ and only 13 of them were married (14.6\%). The descriptive statistics for demographic variables is displayed in Table 1.

Table 1

Descriptive Statistics for Demographic Variables $(n=89)$

\begin{tabular}{llcc}
\hline Variable & Description & Frequency & Percentage \\
\hline Gender & Male & 25 & 28.1 \\
Religion & Female & 64 & 71.9 \\
& Islam & 53 & 59.6 \\
& Christian & 5 & 5.6 \\
& Buddhist & 27 & 30.3 \\
& Hindu & 3 & 3.4 \\
Marital status & Others & 1 & 1.1 \\
Year of & Single & 76 & 85.4 \\
graduation & Married & 13 & 14.6 \\
& 2008 & 3 & 3.4 \\
& 2009 & 12 & 13.5 \\
& 2010 & 14 & 15.7 \\
& 2011 & 19 & 21.3 \\
& 2012 & 41 & 46.1 \\
\hline
\end{tabular}

\section{The Areas of BHM Graduates' Employment}

42 respondents were working in the hospitality industry $(47.19 \%), 16$ were in education $(17.98 \%)$ and 31 were in other industries $(34.83 \%)$ such as child-care, factory, transportation, construction, banking, retailing and computing.

Within the hospitality industry, almost half 17 of the respondents were managers $(40.5 \%)$. The titles of their positions were Human Resources Executive, Human Resources Officer, Senior Travel Consultant, Front Office Assistant Manager, Reservation Executive, Internal Auditor, Event Coordinator, Activity and Recreation Executive, Sales Executive, Sales Coordinator and Catering Service Executive. Five respondents $(11.9 \%)$ held supervisory positions in 
food and beverage, housekeeping and other operational departments. Another 22 respondents (52.4\%) had not made it to the management and supervisory positions. The titles of their positions were Administrative Assistant, Human Resources Assistant, Front Office Assistant, Receptionist, Guest Service Assistant, Guest Experience Assistant, Account Assistant, Sales Support, Room Attendant and Waiter and Waitress.

The majority (6) of those in the education sector were employed as lecturers, and this was followed by teachers (4) and tutors (3). Only one became an executive and an operation manager. Of all the 16 respondents, only one was temporarily employed as a replacement teacher.

Besides the hospitality industry and the education sector, the respondents worked in retailing (7), construction (6), banking (5), computing (2), business (2), income tax (2), transportation (1), factory (1), childcare (1), communication (1), judicial (1), design (1) and handcraft (1). 17 of those who worked (54.84\%) in other industries (excluding education) made it to the management level; one $(3.23 \%)$ at the supervisory level and 13 were still at the non-management level $(41.94 \%)$. The details of the respondents employed in the other industries are displayed in Table 2.

Table 2

\section{Details of Respondents Employed in Other Industries}

\begin{tabular}{|c|c|c|}
\hline Industry & Quantity & Job title \\
\hline \multicolumn{3}{|r|}{ Management } \\
\hline Banking & 4 & $\begin{array}{l}\text { Relationship Manager, Customer Service } \\
\text { Executive, Global Support Executive and Sales } \\
\text { Coordinator }\end{array}$ \\
\hline Transportation & 1 & Bus services HR and Account Executive \\
\hline Business & 1 & Businesswoman \\
\hline Communication & 1 & Mobile Technology Client Services Executive \\
\hline Computing & 2 & Site Training Executive, Sales Support Executive \\
\hline Construction & 3 & $\begin{array}{l}\text { Inventory Controller, Human Resources } \\
\text { Executive and Administrative Executive }\end{array}$ \\
\hline Factory & 1 & Executive \\
\hline Own business & 1 & Manager \\
\hline
\end{tabular}

(continued) 
IJMS 21 (2), 1-20 (2014)

\begin{tabular}{|c|c|c|}
\hline Industry & Quantity & Job title \\
\hline \multirow[t]{2}{*}{ Retailing } & 3 & $\begin{array}{l}\text { Client Relationship Manager, Retail Trainee } \\
\text { Manager and Tenders Manager }\end{array}$ \\
\hline & & Supervisor \\
\hline \multirow[t]{2}{*}{ Retailing } & 1 & Customer Service Assistant Supervisor \\
\hline & & Non-management \\
\hline Banking & 1 & Administrative Assistant \\
\hline Childcare & 1 & Babysitter \\
\hline Construction & 3 & Administrative Clerk \\
\hline Designer & 1 & Clerk \\
\hline Handcraft & 1 & Cashier \\
\hline $\begin{array}{l}\text { Lawyer's office } \\
\text { (judicial) }\end{array}$ & 1 & Clerk \\
\hline LHDN - govt & 2 & Administrative Assistant \\
\hline Retailing & 3 & $\begin{array}{l}\text { Administrative Clerk, Account and } \\
\text { Administrative Assistant, Promoter }\end{array}$ \\
\hline
\end{tabular}

\section{Justification for Seeking Employment in Other Industries}

Only 42 of the 89 employed respondents $(47.19 \%)$ worked in the hospitality industry. 27 of the respondents $(30.34 \%)$ had never been employed in the hospitality industry and 20 left the industry $(22.47 \%)$. 11 of the respondents (12.36\%) left to join the education sector, another 9 joined other industries $(10.11 \%)$. Thus, only 47 respondents answered research question 2. The statistics of the respondents' attachment in the hospitality industry is displayed in Table 3.

Table 3

Statistics of Respondents' Attachment in the Hospitality Industry

\begin{tabular}{lcc}
\hline Situation & Quantity & Per cent \\
\hline Working in the hospitality industry & 42 & 47.19 \\
Never worked in the hospitality industry & 27 & 30.34 \\
Left hospitality industry for education sector & 11 & 12.36 \\
Left hospitality industry for other industries & 9 & 10.11 \\
Total & 89 & 100.00 \\
\hline
\end{tabular}

The following are the explanations given by 47 respondents for seeking employment in the education sector and other industries. 19 themes were identified by employing the thematic content analysis. 
These themes were arranged from the theme mentioned by the highest number of respondents to the least. The themes were: low salary, did not get a job offer, not interested to work in the industry, was offered a better salary in another industry, personal problems, other industries provide better opportunities, uniform does not fulfil the Muslim dress code, more interested in teaching compared to working in an industry, the job in hospitality industry is tiring, long hours at work which result in no social life, hotel does not abide by the rules and regulations, physically unfit to work in the industry, a degree is not a requirement to work in the hospitality industry, social problem, trying to find something new, job offered not up to expectation, the job offer was late, joining family business and reluctant to work on shifts. Table 4 lists the themes and the number of respondents who mentioned the theme.

\section{Table 4}

Reasons for Seeking Employment in Other Industries

Themes Frequency

Low salary

Did not get a job offer

Not interested to work in the industry

Was offered a better salary in other industry

Personal problems

Other industries provide better opportunities

Uniform does not fulfil Muslim ladies' dress code

More interested in teaching compared to working in the industry

The job in hospitality industry is tiring

Long hours at work which result in no social life

Hotel does not abide by the rules and regulations

Physically unfit to work in the industry

A degree is not a requirement to work in the hospitality industry 2

Social problems 2

Trying to find something new $\quad 2$

Job offered not up to expectation $\quad 2$

The job offer was late $\quad 2$

Joining family business 2

Reluctant to work on shifts 2 
A respondent who graduated in 2012 provided a meaningful answer and concluded the answers to the question why hospitality graduates left the industry. The following is the respondent's answer.

"This is not a good industry to start unless we are employed as a management or supervisory staff. The salary is too low for operational staff. The percentage of people hired as management staff is low. Yes, this is a fun and challenging industry but as graduates it will be hard for us to start at the salary of between RM1,400 to RM1,800. We work hard to earn a living but what we got in return is too small. This is the reason why most of us leave the industry. As a degree holder, we do not get the same benefit compared to degree holders in other industries. Most of us left the industry regardless of our seniority".

\section{Discussion}

The number of UUM BHM graduates in the hospitality industry is small. Only 47 per cent of UUM BHM graduates are working in the hospitality industry. This percentage is high compared to the percentage in other countries such as Australia, Hong Kong and Taiwan (Teng, 2008; King et al., 2003). One possible explanation is the competition for skilled employees among the graduates from other industries in the three countries (Australia, Hong Kong and Taiwan) is higher compared to that in Malaysia (Ahmad \& Zainol, 2011). More than half of UUM BHM graduates are working in other industries mainly the education sector followed by retailing, construction, banking and many others in service-related industries. The highest percentage working in the hospitality industry is from the group who graduated in 2012.

The percentage of UUM BHM graduates in the management position is higher in other industries compared to the hospitality industry. Despite having a degree in Hospitality Management, only 40.5 per cent employed in the hospitality industry managed to be in the management level. Better opportunities for career growth (including promotion to management positions) in other industries compared to the hospitality industry have been documented in the literature (Walsh \& Taylor, 2007).

The major reason for UUM BHM graduates seeking employment in other industries is low salary. Other reasons that are not mentioned as frequently are: not getting a job offer, no interest in working in 
the industry, and better salary, opportunities and work conditions in other industries. Another reason, which is rarely mentioned in internationally published literature, is the uniform not meeting the Muslim dress code.

The issue of low salary or poor compensation in the hospitality industry is frequently discussed in the hospitality management literature (Jauhari, 2006; Kang \& Gould, 2002; Teng, 2008; Walsh \& Taylor, 2007). The issue of low salary is also expressed by UUM graduates who managed to secure management positions. As in India, there is an issue of mismatch of supply and demand where the supply of $\mathrm{BHM}$ graduates is larger than the demand for management positions in the industry (Jauhari, 2006). Furthermore, these graduates must compete with hotel supervisory staff for the management position (Ahmad \& Zainol, 2011). Therefore, candidates for the management position who do not have much choice are willing to work for low salary (Jauhari, 2006). This leads to the continuous issue of low salary in the hotel industry.

A few UUM BHM graduates did not get any job offers from the hospitality industry. Mkono (2010) stated that there is high interaction among people of various social, cultural and educational backgrounds in the hospitality industry. Thus, possessing the right kind of personality, which includes having above average interpersonal skill, cultural awareness and sensitivity, is more important compared to formal qualifications. Outgoing and extroverted individuals with good interpersonal and communication skills are more likely to be employed and enjoy hospitality work (Mkono, 2010; Teng, 2008).

Some UUM BHM graduates either had never joined or had left the industry because they were not interested to work in the industry. This was due to the working condition and the nature of the job in the industry. During the peak season, it is common for managers in the hospitality industry to help their subordinates serve customers and some may see this as a mark of a lower status (Mkono, 2010). The "low status" perception of the hospitality job especially in Asian countries is consistent with existing literature (Cheng \& Brown, 1998).

While some refuse to join the industry because of the low status perception, others feel that their personality is not congruent with the industry (Teng, 2008). Some of the UUM BHM graduates were not extroverts, while some perceived that the industry was filled with social problems such as sexual harassment, boundless interaction between genders, and alcoholic beverage sales and consumption. 
Sexual harassment is common among hoteliers. It occurs among employees, and between employees and guests (Ahmad \& Scott, 2014; Eaton, 2004). Among the causes of sexual harassment in the hospitality industry are the "low status" perception of its employees, and the lack of awareness of cultural differences. The "low status" perception here refers to the perception that hotel staff are "cheap and easy". Furthermore, a hotel is a place for some couples to have outof-marriage sex and for others to stay overnight when they are away from home. Ignorance of cultural differences may also lead to sexual harassment. While hugging and kissing between male and female is common among the westerners, it is unethical to the traditional Asians and forbidden to Muslims. To the two latter groups, even taking a photo with them while holding their waists or shoulders will make them feel uncomfortable.

To the Muslims, serving and consuming liquor are forbidden. However, the sale of liquor is in high demand especially in exclusive hospitality organizations, and it is common to see Malaysian Muslims being bartenders. It is also important for hotel managerial employees (especially those in the Sales and Public Relations department) to socialize with the guests or potential guests, and have a "social drink". The non-religious Muslim employees will find consuming liquor a temptation and they usually put their religious beliefs aside. Thus, the religious UUM BHM graduates decide not to join the industry. The challenges of practising Islamic Sharia in the hotel industry is mentioned in multi-disciplined literature (Samori \& Rahman, 2013; Shariff, 2011) but rarely discussed from the workforce and career perspectives.

Some UUM BHM graduates decided not to join the industry because the required uniform did not fulfil the Muslim ladies' dress code. Muslim ladies are required to cover their bodies from head to toe. Many UUM BHM female graduates are Malaysian Muslims who wear the headscarf and cover their figures. When they are offered a job that requires them to wear uniforms, they prefer to turn down the job offer as they refuse to do things that are against their religious practice.

Other reasons why jobs in the hospitality industry appeared unattractive to UUM BHM graduates were the poor working conditions and better salary offered elsewhere. According to the graduates, a job in the hospitality industry was tiring and required 
working on shifts and for long hours. This resulted in the lack of time for the employees' social life. The hard and long working hours made some graduates feel that they were not fit to work in the industry. Thus, some graduates preferred to teach about the industry instead of working in the industry. Few graduates mentioned personal problems, such as having to stay close to and take care of their parents, which made the job in the industry appear unsuitable. There were also graduates who tried to find something new. The issue of other industries offering better salaries and providing better working condition compared to the hospitality industry have been widely documented in the literature (Kang \& Gould, 2002; Raybould \& Wilkins, 2005; Teng, 2008; Walsh \& Taylor, 2007).

\section{Implications of Study}

Attractive and competitive compensation in the hospitality industry is crucial. The issue of inferior compensation in the hospitality industry compared to other industries has been discussed for decades. If no corrective action is taken, the public image of the industry will be distorted and career advisors will suggest having a career in the hospitality industry as a last resort after all options have been considered (Mkono, 2010). This will not only affect the hospitality industry but also the business of hospitality education. The public will find that a BHM education is insignificant because the amount of money earned working in the industry after graduation is too little compared to the amount invested for education. Furthermore, as found in this study, it is frequently mentioned by those employed in the industry that jobs in the hospitality industry do not require tertiary education. This is evident from past studies that discovered a smaller number of hotel managers with a bachelor's degree in comparison to those without a degree who climbed up the career ladder through hard work and years of experience working in the hospitality industry (Ahmad \& Zainol, 2011).

It is crucial that more hospitality organizations start improving their working condition by providing a balance between work and their employees' personal life, and adopting talent development system which includes a career progression policy in order to attract and retain them in the industry (Norma, 1997; Scott \& Revis, 2008; Walsh \& Taylor, 2007). In today's fast-paced economic competition, it is vital for organizations to retain employees as they are an important source to gain and sustain the organization's competitiveness 
(Omar, Mohamed Anuar, Abdul Majid \& Johari, 2012). Some hospitality organizations do provide graduates with attractive compensation and working conditions but the number is still very small (Mkono, 2010).

Strategic human resources management suggests that hospitality businesses be adaptable to their environment by considering factors such as rules and regulations and the culture and beliefs of the local community (Ahmad, Solnet, \& Scott, 2010). Malaysia is a multi-racial country with a population of various religious beliefs. The Malay Muslims comprise of the majority of the population and thus Islam is the official religion of the country (Samori \& Rahman, 2013). Despite Malaysia being a Muslim country, many hospitality organizations here, especially four-and five-star hotels require their employees to wear uniforms that do not reflect the official religion of the country. While it is true that many investors and guests of the luxurious hospitality establishments in Malaysia are non-Muslims (Samori \& Rahman, 2013), flexibility in the employees' uniform will benefit all stakeholders. The employer will have a bigger pool of qualified candidates to fill job vacancies, the graduates will have more job options, and the guests will see various identities of Malaysians. Furthermore, there is an increasing number of Muslim tourists in Malaysia who will be delighted to find those of similar faith serving them in a foreign country (Samori \& Rahman, 2013).

The issues faced by the Muslim graduates in this study highlight the need for more Shariah compliant hotels. There is a growing interest in the development of Shariah compliant hotels (Samori \& Rahman, 2013). Based on Henderson (2010) and Samori and Rahman (2013), a Shariah compliant hotel refers to a hotel that abides by the Shariah standard in all its practices-from cleaning to accounting. Shariah is the basis for Muslims, guided by the Holy Quran and sunnah (the customs of Prophet Muhammad). Among the characteristics of Shariah compliant hotels are serving halal food and beverages (no alcohol), providing prayer room(s) and items, i.e. the Holy Quran, prayer mat and qiblat indicator, no entertainment forbidden by the Holy Quran and sunnah, predominantly Muslim staff adhering to the Islamic dress code, having separate facilities for men and women, i.e. salons, recreational facilities and swimming pools, providing separate rooms for singles (not married) of different gender, and setting up tourists' dress code and Islamic funding (Samori \& Rahman, 2013). The increasing number of Shariah compliant hotels in Malaysia will 
provide a suitable working atmosphere for the religious Muslim UUM BHM graduates. These hotels will provide employment opportunities and attract the graduates to work in the hospitality industry.

In line with Raybould and Wilkins (2005), it is beneficial for the UUM $\mathrm{BHM}$ programme to have a business and entrepreneurial-oriented BHM curriculum. More than half of the UUM BHM graduates join other industries that range from the service industry such as banking and retailing to the construction business. Most of the posts that the graduates hold in these industries are related to mainstream business management courses such as human resources management, accounting, customer service management, operation management and sales and marketing. The fact that the hospitality industry requires a limited number of managers (Jauhari, 2006) and other industries provide better career development opportunities and working conditions (Teng, 2008; Walsh \& Taylor, 2007) indicates that the UUM BHM programme should restructure its curriculum to prepare its graduates to be more versatile. The graduates should be groomed to work in the hotel industry (Alexander, 2007) and other industries as well. This can be done by incorporating the business-related courses mentioned above. Included in the syllabus of the courses should be the application of the subject in the hospitality businesses. Nonetheless, it is important to include courses that will enhance students' soft skills (such as interpersonal and entrepreneurial skills) in the curriculum. To create a balanced curriculum, vocational and action-based courses have to co-exist with philosophical business and management courses (Alexander, 2007). While it is important to tailor the curriculum to meet the needs of the hospitality industry, the university's obligation to its students and the society should not be neglected. It is ethical for the UUM BHM programme to aim at producing graduates who are successful in their career regardless of the type of industry they are attached to. Employers in the hospitality industry must recognize that employers from other industries are willing to offer skilled hospitality graduates competitive compensations and better working conditions, which can result in a high cost of staff turnover and wastage of trained personnel in the hospitality sector (O'Leary \& Deegan, 2005).

\section{Conclusion}

This research has theoretical and practical contributions. Theoretically, it contributes to the Malaysian hospitality education literature by providing knowledge of hospitality graduates' justifications 
for leaving the industry from an under-researched perspective. Practically, tracing graduates' employment areas and explanations for leaving the hospitality industry benefits hospitality students, the universities and the hospitality industry. This study provides information of the UUM graduates' employment areas, the jobs they do, the number of graduates who pursue their career in the hospitality industry, and their explanation for leaving the industry. Such information will educate BHM students on their expectations, guide them in their career plans, and prepare them to face the industry. As for the industry, the findings are useful for them to take corrective actions and make further improvements in order to attract and retain skilled employees, while the university can groom the students to meet the needs of the industry. Although the UUM BHM curriculum is not the focus of this study, it indirectly helps in the initiative to improve the curriculum.

This study has several limitations. Very few of the suggestions in the implication section are given by the respondents. This is merely a descriptive study with the objective of assessing the graduates' area of employment and justifications for leaving the industry. Thus, respondents were not asked about how the UUM BHM programme could help them to achieve the management position (career growth), and how the hospitality industry could attract and retain skilled workers among their graduates. Future studies could address these questions from various perspectives to add value to the findings of this study. Future studies could also adopt the quantitative method to assess graduates' reasons for leaving the hospitality industry in order to generalise the findings.

\section{References}

Ahmad, R., \& Scott, N. (2014). Managing the front office department: Staffing issues in Malaysian hotels. An International Journal of Tourism and Hospitality Research, 25(1), 24-38.

Ahmad, R., Solnet, D., \& Scott, N. (2010). Human resource practices system differentiation: A hotel industry study. Journal of Hospitality $\mathcal{E}$ Tourism Management, 17, 72-82.

Ahmad, R., \& Zainol, N. (2011). What it takes to be a manager: The case of Malaysian five-star hotels. In Proceedings of the $2^{\text {nd }}$ International Conference on Business and Economic Research, Langkawi, Malaysia. 
Alexander, M. (2007). Reflecting on changes in operational training in UK hospitality management degree programmes. International Journal of Contemporary Hospitality Management, 19(3), 211-220.

Cheng, A., \& Brown, A. (1998). HRM strategies and labour turnover in the hotel industry: A comparative study of Australia and Singapore. The International Journal of Human Resource Management, 9(1), 136-154.

Eaton, D. E. (2004). Beyond room service: Legal consequences of sexual harassment of staff by hotel guests. Cornell Hotel and Restaurant Administration Quarterly, 45, 347-361.

Enache, M., Sallan, J. M., Simo, P., \& Fernandez, V. (2011). Examining the impact of protean and boundaryless career attitudes upon subjective career success. Journal of Management \& Organization, 17(4), 459-473.

Henderson, J. C. (2010). Sharia-compliant hotel. Tourism and Hospitality Research, 10(3), 246-254.

Jauhari, V. (2006). Competencies for a career in the hospitality industry: An Indian perspective. International Journal of Contemporary Hospitality Management, 18(2), 123-134.

Kang, S. K., \& Gould, R. (2002). Hospitality graduates' employment status and job satisfaction. Journal of Hospitality and Tourism Education, 14(4), 11-18.

King, B., McKercher, B., \& Waryszak, R. (2003). A comparative study of hospitality and tourism graduates in Australia and Hong Kong. International Journal of Tourism Research, 5, 409-420.

Ladkin, A. (2002). Career analysis: A case study of hotel general managers in Australia. Tourism Management, 23, 379-388.

Lashley, C. (2011). University challenge: Sharing some experiences of engaging with industry. International Journal of Contemporary Hospitality Management, 23(1), 131-140.

McKercher, B., Williams, A., \& Coghlan, I. (1995). Career progress of recent tourism graduates. Tourism Management, 16(7), 541-549.

Ministry of Higher Education (MOHE). (2013). Laman rasmi SKPG1. Retrieved from http://graduat.mohe.gov.my

Mkono, M. (2010). In defence of hospitality careers: Perspectives of Zimbabwean hotel managers. International Journal of Contemporary Hospitality Management, 22(6), 857-870.

Norma, D. G. (1997). Developing international managers in the hospitality industry. International Journal of Contemporary Hospitality Management, 9(5/6), 199-208.

O'Leary, S., \& Deegan, J. (2005). Career progression of Irish tourism and hospitality management graduates. International Journal of Contemporary Hospitality Management, 17(4/5), 421-432. 
Omar, K., Mohamed Anuar, M., Abdul Majid, A. H., \& Johari, H. (2012). Organisational commitment and intention to leave among nurses: The mediating role of moral obligation. International Journal of Management Studies, 19(2), 31-46.

Patah, M. O., Zain, R. A., Abdullah, D., \& Radzi, S. M. (2009). An empirical investigation into the influences of psychological empowerment and overall job satisfaction on employee loyalty: The case of Malaysian front office receptionists. Journal of Tourism, Hospitality and Culinary Arts, 43-62.

Raybould, M., \& Wilkins, H. (2005). Overqualified and underexperienced: Turning graduates into hospitality managers. International Journal of Contemporary Hospitality Management, 17(2/3), 203-216.

Richardson, S., \& Butler, G. (2011). Attitudes of Malaysian tourism and hospitality students' towards a career in the industry. Asia Pacific Journal of Tourism Research, 1, 1-15.

Ryan, C., Ghazali, H., \& Mohsin, A. (2011). Determinants of intention to leave a non-managerial job in the fast-food industry in West Malaysia. International Journal of Contemporary Hospitality Management, 23(3), 344-360.

Samori, Z., \& Rahman, F. A. (2013). Towards the formation of Shariah compliant hotel in Malaysia: An exploratory study of its opportunities and challenges. In Proceedings of the 2013 WEI International Academic Conference, Istanbul, Turkey.

Scott, B., \& Revis, S. (2008). Talent management in hospitality: Graduate career success and strategies. International Journal of Contemporary Hospitality Management, 20(7), 781-791.

Shariff, N. M. (2011). Reforming hospitality program of higher educational institutions. An International Journal of Tourism and Hospitality Research, 22(1), 125-128.

Teng, C. C. (2008). The effects of personality traits and attitudes on student uptake in hospitality employment. International Journal of Hospitality Management, 27, 76-86.

Walsh, K., \& Taylor, M. S. (2007). Developing in-house careers and retaining management talent: What hospitality professionals want from their jobs. Cornell Hotel and Restaurant Administration Quarterly, 48(2), 163-182.

Zahari, M. S., Hanafiah, M. H., Othman, Z., Jamaluddin, M. R., \& Zulkifly, M. I. (2010). Declining interest of hospitality students toward careers in hotel industry: Who's to be blamed? Interdisciplinary Journal of Contemporary Research in Business, 2(7), 269-287. 